\title{
Silicification of Developing Internodes in the Perennial Scouring Rush (Equisetum hyemale var. affine)
}

\author{
Peter B. Kaufman, J. Donald LaCroix ${ }^{1}$, and P. Dayanandan \\ Department of Boluny, University of Michigan, Ann Arbor, Michigan 48104
}

AND

Lawrence F. Allard, Jonathan J. Rosen, and Wilbur C. Bigelow

Department of Materials and Metallurgical Engineering, University of Michigan, Ann Arbor, Michigan 48104

\author{
Accepted September 22, 1972
}

\begin{abstract}
An electron microprobe (EMP) analysis of silica $\left(\mathrm{SiO}_{2}\right)$ deposition in the epidermis of developing internodes of the perennial scouring rush (Equisetum hyemale var. affine) indicates that $\mathrm{SiO}_{2}$ is first detected in the stomatal apparatus beginning with internode 3 , then the epidermal papillae (internode 8), and finally in radial cell walls of the long epidermal cells (internode 10). This process is initiated in the intercalary growth regions at the bases of the elongating internodes. The deposition of $\mathrm{SiO}_{2}$ in long epidermal cell walls occurs after internodal extension has ceased and should therefore be considered as one of the final stages in internodal differentiation that involves strengthening the cellulosic framework of the cell wall. EMP measurements indicate that $\mathrm{SiO}_{2}$ in stomata is equivalent to $30 \%$ of a pure $\mathrm{SiO}_{2}$ standard and that $\mathrm{SiO}_{2}$ in the radial walls of long epidermal cells averages twice that measured on the tangential walls of these same cells. This study supports the view that silicification plays a major role in strengthening the developing perennial scouring rush internodal system and that regulation of this process in this and other species of Equisetum, whose $\mathrm{SiO}_{2}$ deposition patterns are markedly different, deserves further study.
\end{abstract}

\section{INTRODUCTION}

Silica is deposited as opal $\left(\mathrm{SiO}_{2} \cdot n \mathrm{H}_{2} \mathrm{O}\right.$ with low water of hydration) or silica gel $\left(\mathrm{SiO}_{2} \cdot n \mathrm{H}_{2} \mathrm{O}\right.$ with high water of hydration) in the epidermis and in other tissues (pith, cortex, mesophyll, and vascular bundles) of many plants (Lewin and Reimann, 1969). It occurs in significant quantities in silica-rich plants such as horsetails (Equisetaceae), grasses (Gramineae), sedges (Cyperaceae), nettles (Urticaceae), diatoms (Chrysophyta), golden algae (Xanthophyta), and other plants (Küster, 1951; Lewin, 1962) as well as in spicules of sponges (Porifera) and radiolarians (Protozoa) (Lewin and Reimann, 1969). Using electron microprobe X-ray microanalysis, Schafer and Chandler (1970), reported the presence of silicon in the centriole in a section of

${ }^{1}$ Present address: Department of Biology, University of Detroit, Detroit, Michigan 48221. the dorsal renal tubule of a guinea pig, while Carlisle (1970) located silicon in an early stage of bone calcification of the normal tibia in young mice and rats.

The scouring rushes (Equisetum spp.). are known to accumulate relatively large amounts of silica which may reach up to $16 \%$ dry weight in Equisetum arvense (Lewin and Reimann, 1969). In silica-rich mature epidermal cells of $E$. hyemale, the perennial scouring rush, the silica content, compared with pure $\mathrm{SiO}_{2}$ varies between 57 and $85 \%$ (Kaufman et al., 1971). Timell (1964) reported that the silicic acid content in E. palustre may be as much as $25.3 \%$ of the dry weight. Although silica is usually confined to the aerial portions of the shoot system, trace amounts in the roots of $E$. arvense have been reported by Laroche (1969); he has further suggested (Laroche, 1968) that silica absorbed by the plant may be trans- 
ported to the shoot system. In an analysis of the way in which silica moves into typical silica-accumulator plants, Lovering and Engel (1967), using E. hyemale, concluded that the biochemical action taking place at the roots must solubilize the raw rock with which the roots are in contact so as to allow the uptake of silica as silicic acid. Chen and Lewin (1969) observed that silicon (as sodium metasilicate, $\mathrm{Na}_{2} \mathrm{SiO}_{3}$. $9 \mathrm{H}_{2} \mathrm{O}$ ) is an essential element for healthy development of $E$. arvense.

Very few studies have been made on the silicification process during development of shoots of silica-rich plants such as Equisetum. Most studies have dealt primarily with silica in mature, fully developed tissues of plants (e.g., Equisetum: Laroche, 1967, 1968, 1969; Laroche et al., 1970; Kaufman et al., 1971). Such developmental studies are necessary to unravel the regulatory mechanisms of silica deposition in silica-rich species and to learn how this process acts in braking growth in differentiating cells. Thus, this study on the silica deposition process in developing Equisetum internodes was made with the following objectives in mind: (1) to determine the distribution patterns of silica in the epidermal system with special emphasis on developing stomatal apparatuses in the elongating shoot internodes and (2) to compare the silica deposition pattern in the perennial scouring rush (Equisetum hyemale var. affine) with that in the annual scouring rush ( $E$. arvense). The significance of the silicification process to development of the shoot system in the scouring rushes is discussed in light of the results presented here.

\section{MATERIALS AND METHODS}

Shoots were obtained from a culture of the perennial scouring rush, E. hyemale var. affine which had been maintained in the greenhouse at the University of Michigan Matthaei Botanical Gardens. This culture was established from plants that had been collected from a single site in the vicinity of the University of Michigan Biological Station at Douglas Lake, Michigan.

Peels of outer epidermal tissue were made from successive developing internodes of one shoot. These peels were taken from the top, middle, and base of each internode. Beginning at the apex of the shoot, the lengths of the internodes in this shoot were as follows: internode 1 (2 $\mathrm{mm}), 2(4 \mathrm{~mm}), 3(6 \mathrm{~mm}), 4(8 \mathrm{~mm}), 5$ $(9.5 \mathrm{~mm}), 6(11 \mathrm{~mm}), 7(12.5 \mathrm{~mm}), 8$ (12.5 $\mathrm{mm}), 9(10 \mathrm{~mm})$, and a mature internode $(30 \mathrm{~mm})$. Peels were also obtained from a second shoot with internodes at comparable stages of development from the same culture to verify the data obtained from the initial shoot and to complete the analysis of all required internodes.

For scanning clectron microscopy, the peels of living tissue were mounted with electrically conductive silver paint directly on aluminum stubs and examined immediately. To observe the details of lower stomatal structures with the scanning electron microscope (JEOL Model JSM-U3), hereafter referred to as the SEM, very thin epidermal peels freed from all cortical tissue were made either from fresh specimens or from material that had been boiled in $10 \% \mathrm{NaOH}$. The latter treatment gave better resolution. Floating the peel over concentrated $\mathrm{H}_{2} \mathrm{SO}_{4}$ resulted in the progressive disappearance of cellular details, and in $15 \mathrm{~min}$, only the cuticular layer remained. The peels were mounted on aluminum foil and the latter in turn were mounted on aluminum stubs with silver paint. All material was coated with chromium. For examination of cross and longitudinal views of the stomatal apparatus with the SEM, paraffin-embedded tissue was sectioned at $15 \mu$. Sections were mounted on aluminum foil with Haupt's adhesive, treated with xylene-tert-butyl alcohol to remove the paraffin, dried at room temperature, and mounted on aluminum stubs. 
The SEM was normally operated at 25 $\mathrm{KeV}$ accelerating potential, but in several instances, lower voltages were used to minimize charging artifacts in the images. SEM secondary electron images were recorded on Polaroid Type $55 \mathrm{P} / \mathrm{N} 4 \times 5$ film.

For electron probe analysis, the peels of tissue were placed in $2 \mathrm{~cm}^{2}$ aluminim foil envelopes, immediately frozen in liquid nitrogen, and then freeze-dried in a vacuum desiccator in a deep freeze for $48 \mathrm{hr}$. The dried pieces were mounted on polished, copper squares with electrically conductive silver paint. The tissue was then coated with a thin layer of carbon and stored in a desiccator until examination in the electron microprobe (Applied Research Laboratories, model EMX-SM), hereafter referred to as the EMP.

The EMP was operated at $20 \mathrm{KeV}$, giving an electron beam penetration into the tissue of about $15 \mu \mathrm{m}$. The average thickness of the epidermal layer is also $15 \mu \mathrm{m}$. The beam current was $0.20 \mu \mathrm{amp}$, giving a sample current of $0.021 \mu \mathrm{amp}$. The $\mathrm{X}$-ray spectrometer was peaked for the first-order silicon $\mathrm{K} \alpha$ line using an am- monium dihydrogen phosphate (ADP) crystal. Secondary electron images were employed to examine the tissue and to select cells for analysis. EMP secondary electron and X-ray images were recorded on Type 42 Polaroid Polapan Land Roll $3 \frac{1 / 4}{4} 4_{1 / 4}$ film.

A semiquantitative comparison of differing Si levels was made in conjunction with the Si X-ray distribution maps for each tissue section. This digital information has been reported (Table 1) as the ratio of counts taken on the sample (peak minus background) to the counts taken on a pure $\mathrm{Si}$ standard (peak minus background) under constant and identical instrument conditions. This probe ratio does not represent an exact weight percentage for the amount of Si present because no correction has been made for fluorescence, absorption, or atomic number effects (Beaman and Isasi, 1971). Electronic drift effects have been automatically corrected by using current controlled counting times. Although the probe ratio does not represent an exact weight percent, it does afford a more precise measure of relative values and a semi-quantitative comparison with respect to pure

TABLE 1

Electron Probe Microanalysis of $\mathrm{SiO}_{2}{ }^{a}$ in Stomata of Developing Internodes of the Perennial Scouring Rush, Equisetum hyemale var. affine

\begin{tabular}{|c|c|c|c|c|c|c|}
\hline \multirow{3}{*}{$\begin{array}{l}\text { Internode number, } \\
\text { top to base of } \\
\text { shoot }\end{array}$} & \multicolumn{6}{|c|}{ Region of internode } \\
\hline & \multicolumn{2}{|c|}{ Top } & \multicolumn{2}{|c|}{ Middle } & \multicolumn{2}{|c|}{ Base } \\
\hline & Edge $^{o}$ & End $^{b}$ & Edge & End & Edge & End \\
\hline 1 & $n o c^{c}$ & noc & - & - & noc & noc \\
\hline 2 & noc & noc & - & - & noc & noc \\
\hline 3 & 0.09 & 0.16 & - & - & 0.07 & 0.21 \\
\hline 4 & 0.14 & 0.18 & - & - & 0.07 & 0.12 \\
\hline 5 & - & - & - & - & 0.18 & 0.40 \\
\hline 6 & 0.28 & 0.19 & 0.28 & 0.15 & 0.12 & 0.05 \\
\hline 7 & 0.30 & 0.29 & 0.24 & 0.22 & - & - \\
\hline 8 & 0.25 & 0.17 & 0.40 & 0.25 & - & - \\
\hline 9 & - & - & 0.36 & 0.40 & - & - \\
\hline 10 & - & - & 0.38 & 0.31 & - & - \\
\hline
\end{tabular}

${ }^{a}$ Expressed as probe ratio (see Materials and Methods).

${ }^{\circ}$ Edge = edge of stomatal aperture; End = end of stomatal subsidiary cells.

${ }^{c}$ noc $=$ no obvious $\mathrm{SiO}_{2}$ concentrations above background. 
Si than reporting the raw data as counts per second. To approximate the weight percent of $\mathrm{SiO}_{2}$ present on the samples, a standard probe ratio of counts on an $\mathrm{SiO}_{2}$ standard versus counts on an $\mathrm{Si}$ standard was obtained. This value was used to modify the Si-based probe ratios.

Silicon ( $\mathrm{Si}$ ) is associated with oxygen as silica $\left(\mathrm{SiO}_{2}\right)$ in biological material and is deposited in many plant species, including the Equisetaceae, in the form of silica gel or hydrated amorphous silica, $\mathrm{SiO}_{2}$. $n \mathrm{H}_{2} \mathrm{O}$ (Lewin and Reimann, 1969; Laroche, 1968). Here, $\mathrm{Si}$, rather than $\mathrm{SiO}_{2}$, was measured because of the difficulty of measuring oxygen directly with the EMP, especially in biological material.

\section{RESULTS}

\section{SEM Analysis of Shoot Epidermal Topog- raphy}

The SEM analysis of the epidermal system was undertaken so that we could delineate the surface topography and types of cells which we wished to analyze for Si by EMP in the developing internodes of the perennial scouring rush. SEM views of the epidermal surfaces are far more satisfactory for this purpose than secondary electron images obtained with the EMP.

The shoot epidermal system of the plant basically consists of a matrix of parallel series of long epidermal cells. Intercalated in this matrix are double files of stomata (Figs. 1-3) lying on the sloping sides of the internodal furrows. These stomata can be observed at different stages of development in the intercalary meristem (IM) growth zones at the extreme bases of each of the elongating internodes. Thus, the stomata differentiate in an extremely restricted zone (ca. $1 \mathrm{~mm}$ long) at the base of each elongating internode.

The surfaces of the long epidermal cells lying in the furrows between the double rows of stomata are covered with knobs which are clearly observed in young,

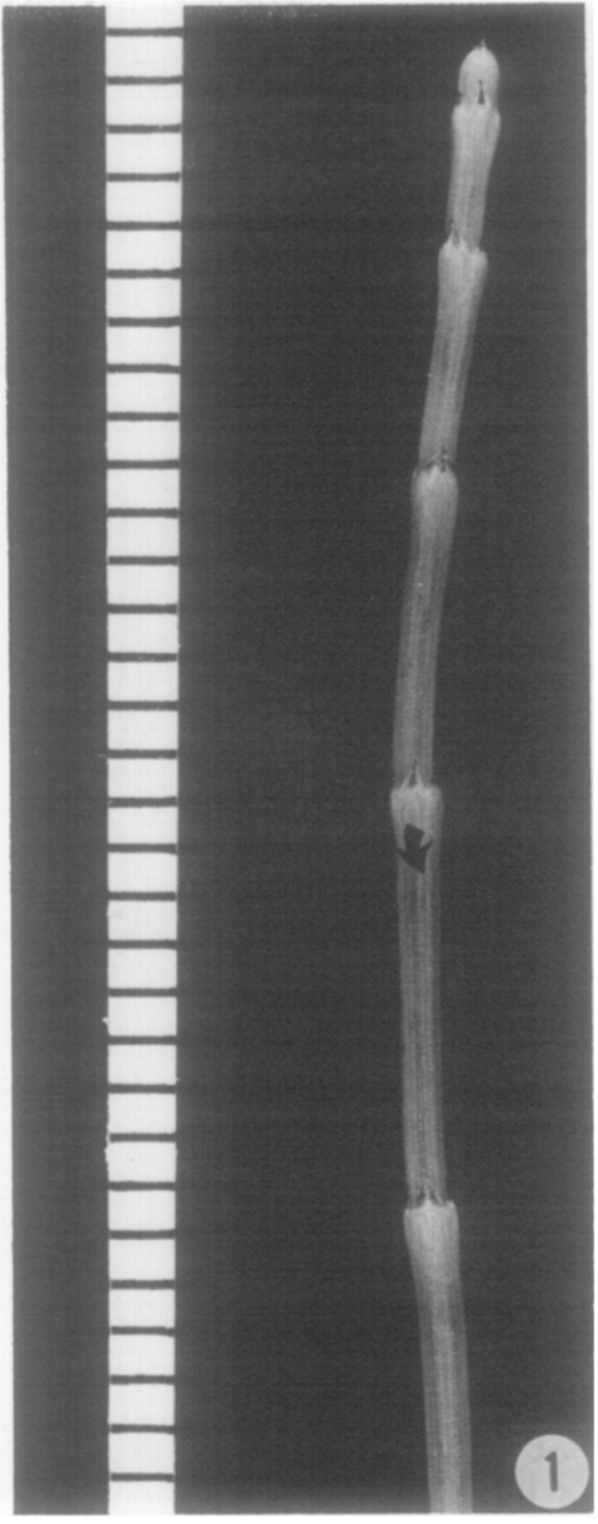

Fig. 1. Shoot of Equisetum hyemale var. affine showing double files of stomata (arrow). Each unit on scale equals 1 inm. $\times 4.5$.

rapidly elongating internodes (Figs. 2 and 3). These knobs are basically made up of cutin or waxes and later become impregnated with silica (Fig. 17). The knobs are somewhat papillate (Figs. 4 and 5). In older internodes, the knobs become obscured by irregular sheets of wax or cutin which cover them (Figs. 6 and 7).

On the ridge, between the double rows of stomata, are long epidermal cells which 

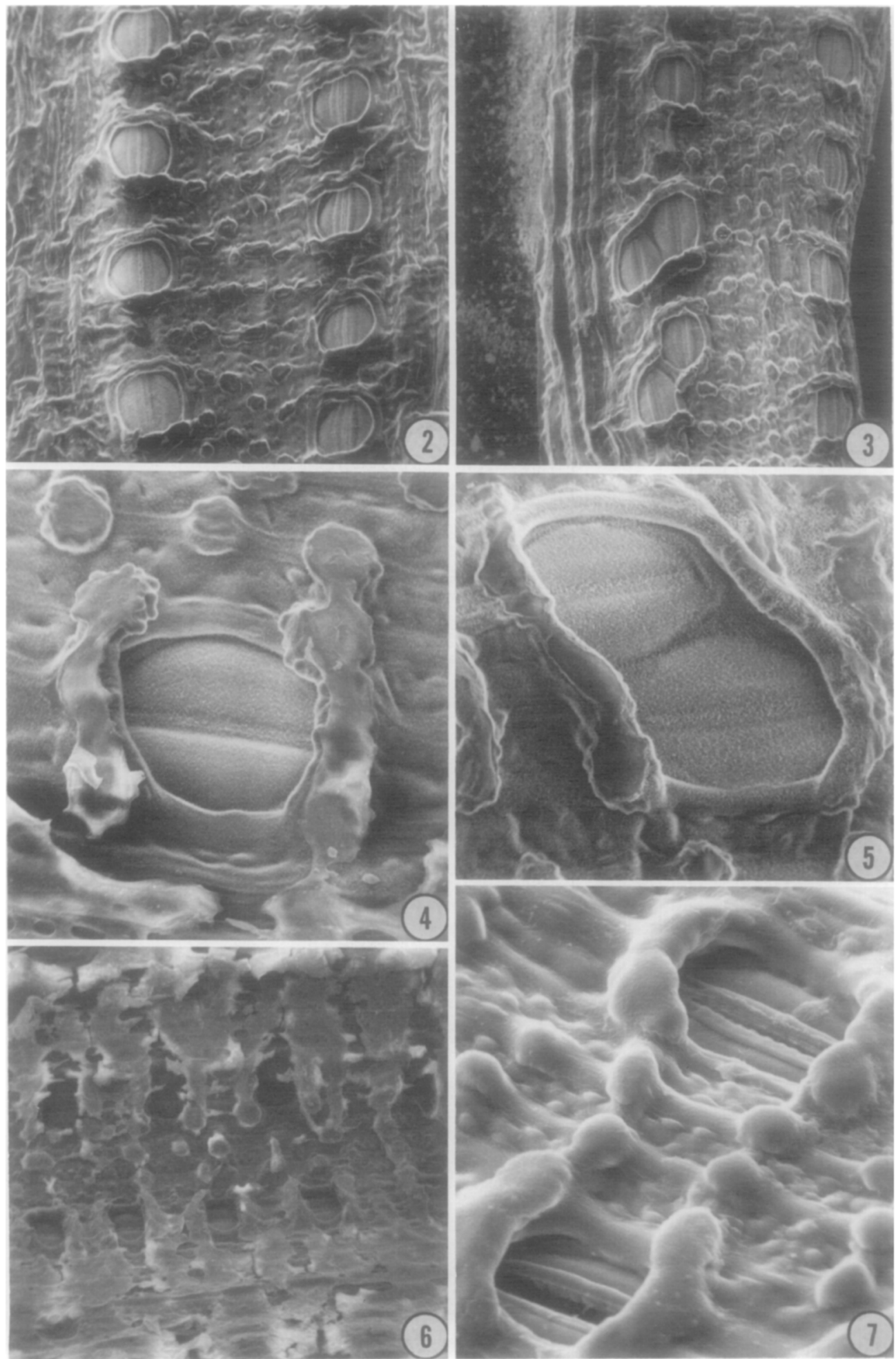
have horizontal series of large knobs on their outer surfaces. These knobs in mature internodes become covered with conspicuous masses of cutin and silica (Fig. 6).

The stomata usually occur singly (Fig. 4) or as doublets (Fig. 5). They are typically surrounded by a rounded ridge (Figs. 4,5 , and 7). The two hemispherical cells seen within this encircling ridge are the two subsidiary cells of the stomatal apparatus. Their outer surfaces are covered with fine, heterogeneously dispersed fibrillar material, presumably cuticle. In Fig. 7, the lowermost stomatal subsidiary cells are open, revealing the thickened "lips" at the periphery of the stomatal aperture and the undulate ends of ridges below the surface but within the aperture (cf. Figs. 7-9). Closer examination of the stomata, using sheets of epidermal tissue that have been lysed away from internal tissues by means of acid treatment or other methods (see Materials and Methods), affords a better understanding of the complex structure of these stomata. Figure 8 shows two rows of stomata viewed from the inside of the outer epidermis after removal by $\mathrm{H}_{2} \mathrm{SO}_{4}$ of all cellulosic material. The herringbone pattern of ridges seen in the center of each stomatal apparatus occurs on the undersides of the subsidiary cells described above and shown in Figs. 4, 5, and 7. These ridges form a double series (Fig. 9) almost like a double hinge.

Below the subsidiary cells with their ridgelike thickenings, lie the two guard cells (Figs. 10 and 11) with an aperture between them (Fig. 11). This means that there are two possible "control points" for stomatal opening and closing: the aperture between the two subsidiary cells (Fig. 7) and the one between the two guard cells (Fig. 11). Both must be considered in relation to any mechanism regulating opening and closing these stomata (Ricbner, 1925).

\section{EMP Analysis of Silica Deposition in Developing Internodes}

The X-ray analysis with EMP indicates that $\mathrm{SiO}_{2}$ is deposited primarily in three sites in the epidermal system of the developing internode: (1) stomatal apparatuses (Figs. 13, 15, 17, and 19); (2) the epidermal knobs (Fig. 17); and (3) the papillae along the radial walls of long epidermal cells (Figs. 7 and 19). The stomatal apparatuses accumulate the largest amount of silica. The probe ratio data indicate that they may contain up to $40 \%$ $\mathrm{SiO}_{2}$ compared with a pure $\mathrm{SiO}_{2}$ standard. A typical stomatal apparatus, in a nearly fully elongated internode (No. 8, $12.5 \mathrm{~mm}$ long), had the following $\mathrm{SiO}_{2}$ values expressed as probe ratios: edge of stomate opening $=0.40$; end of stomate opening on peripheral edge $=0.25$; on surface of subsidiary cell $=0.05$; the background was 0.00 . Figure 16 indicates these particular sites in a stomatal apparatus, and Fig. 17 illustrates the X-ray scan, showing in a qualitative way a verification of these probe ratio data on $\mathrm{SiO}_{2}$. The data clearly indicate that the greatest amount of $\mathrm{SiO}_{2}$

FIG. 2. View of middle of internode 5. Double file of stomata separated by long epidermal cells bearing knobs. $\times 225$.

FIG. 3. View of tip of internode 2. Surfaces of long epidermal cells between single and double stomata covered with knobs made up of cutin or waxes which become impregnated with silica. At left are long epidermal cells lying on top of internodal ridge. These cells are not covered with knobs. $\times 225$.

FIG. 4. View of base of a mature internode. Two subsidiary cells of stomatal apparatus closed and surrounded by ridge and papillate knobs. $\times 750$.

FIG. 5. View of tip of internode 2 . Double stomata in a single crypt. $\times 750$.

Fig. 6. View of tip of a mature internode showing waxy encrustations over epidermal surface. $\times 225$.

FIG. 7. View of internode 8 . Subsidiary cells illustrating ridgelike wall thickening surrounding stomatal aperture. Lower stomate open due to $\mathrm{NaOH}$ treatment; they are usually closed in situ. $\times 675$. 

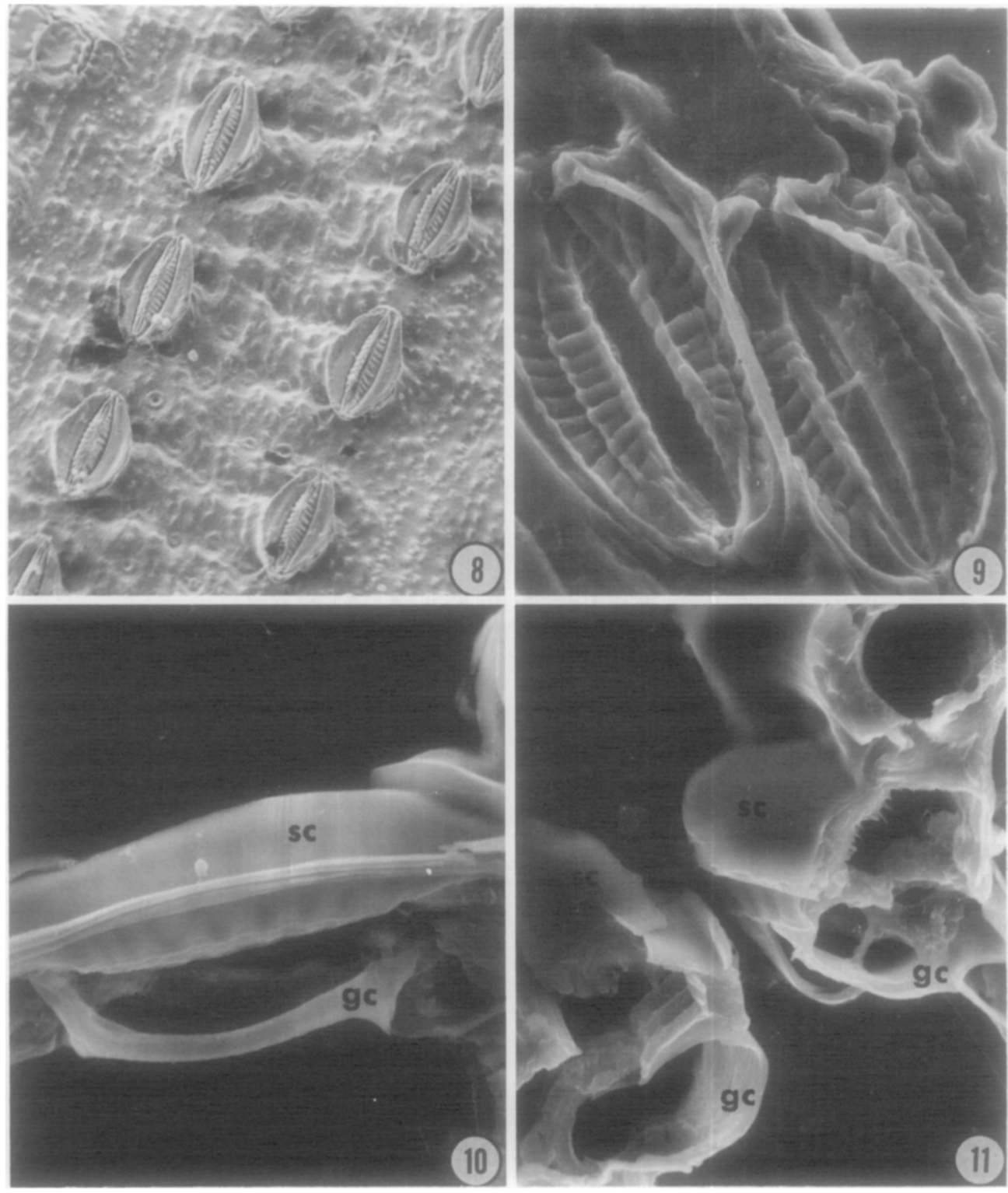

Fig. 8. View of internode 8. Undersurface view of isolated cuticle showing herring-bone structure on subsidiary cells. $\times 225$.

Fig. 9. View of internode 8 . Ridges of subsidiary cells seen from above after removal of upper wall. $\times 900$.

Fig. 10. Structural relationship between upper subsidiary cells $(s c)$ and lower guard cells $(g c) . \times 1500$.

Fig. 11. Aperture between two subsidiary cells $(s c)$ and two guard cells $(g c) . \times 1500$.

is concentrated along the stomatal aperture in the inner walls of the subsidiary cells. Lesser but significant amounts occur in the walls and ridges at the ends of these cells. Only trace amounts were detected on the paradermal outer walls of the subsidiary cells. This accounts for the girder-shaped $\mathrm{SiO}_{2}$ deposition pattern seen in Fig. 17.

In the epidermal knobs on the surfaces of the long epidermal cells, the probe ratio data indicate typical $\mathrm{SiO}_{2}$ values varying between 0.27 and 0.38 for internodes 8 and 10 . This is in the same range of 
values as for stomatal apparatuses. In internode 4, these knobs, now at a much earlier stage in their development, had probe ratios of only $0.01-0.02$, which is not significantly above background $(0.01-$ 0.02). Thus, these knobs become silicified very late in their development; $\mathrm{SiO}_{2}$ greater than background was first recorded in internode 8 , which is nearly fully elongated. This contrasts with stomata, where $\mathrm{SiO}_{2}$ greater than background was first detected in internode 3 (Table 1 ), which is only about one-half its final length.

In the papillae along the long epidermal cell radial walls, we find first detectable $\mathrm{SiO}_{2}$ greater than background in internode 10 , one that is fully elongated. Typical probe ratios indicate values of 0.07 in the radial cell wall and 0.02 in the outer tangential walls of these same cells. Such selective $\mathrm{SiO}_{2}$ deposition in the radial cell walls can be seen in Figs. 18 and 19. This deposition of $\mathrm{SiO}_{2}$ in these cell walls occurs very late in internodal development and clearly has developmental significance in strengthening the cell wall. Internodes at the level of number 10 and older are significantly stiffer than those nearer the tip where no $\mathrm{SiO}_{2}$ can be detected in long radial epidermal cell walls. EMP observation of 2-yr-old shoots of the perennial scouring rush indicate that the last portions of the epidermal system to become silicified are the outer tangential walls of the long epidermal cells (Figs. 22 and 23). The stomata crypts (in which the stomata lie) show no detectable silica (Fig. 23) because the crypt (Fig. 24) exceeds the depth of penetration of the probe electron beam (ca. $15 \mu \mathrm{m}$ for $20 \mathrm{KeV}$ ). We obtained direct proof for this with cellulose acetate replicas (Fig. 25), where the two projections are equivalent to the stomatal crypts and clearly exceed $15 \mu \mathrm{m}$ in height (ca. 65 $\mu \mathrm{m}$ ). These crypts become greater in depth as the epidermis differentiates due to succeedingly greater amounts of cutin and silica secreted on the outer surface of the epidermis.
Table 1 illustrates probe ratio data for $\mathrm{SiO}_{2}$ in stomata in successively older internodes of a perennial scouring rush shoot, starting with the first macroscopically detectable internode below the shoot apex. The data indicate that no $\mathrm{SiO}_{2}$ could be detected in the first two internodes below the shoot apex in any of the stomata nor any of the long epidermal cells in apical or basal peels of tissue. The first detectable $\mathrm{SiO}_{2}$ was found in internode 3 in both apical and basal positions of the internodal epidermis. It is of considerable interest in this connection that in the basal peel, containing a portion of the intercalary meristem, where new stomata are generated, $\mathrm{SiO}_{2}$ was detected in the differentiating stomatal apparatuses. As one progresses to succeedingly older internodes, the $\mathrm{SiO}_{2}$ probe ratio values in stomatal apparatuses increase (Table 1), rcaching maximal levels by internode 8 , which has fully elongated.

\section{DISCUSSION}

The present study with EMP has shown that $\mathrm{SiO}_{2}$ is first detected in the epider$m$ is of internodes of the perennial scouring rush in the stomatal apparatuses, when internodes are first elongating; then in the epidermal papillae, when internodes are about half elongated; and finally in the long epidermal cell walls (radial, then outer tangential walls), when internodes have essentially ceased elongation. This sequential deposition of $\mathrm{SiO}_{2}$ has developmental significance in that: (1) the late deposition of silica in the cell walls would provide a means by which the walls could still undergo plastic extension growth before silica deposition; (2) the final silicification of these walls could provide a mechanism by which the cell lengthening process gradually comes to a halt; and (3) the intercalation of $\mathrm{SiO}_{2}$ within the cellulosic framework of the cell wall (Siegel, 1968; Laroche, 1969) would ensure support for the fully elongated internode. The $\mathrm{SiO}_{2}$ we have observed by $\mathrm{X}$-ray analysis in 

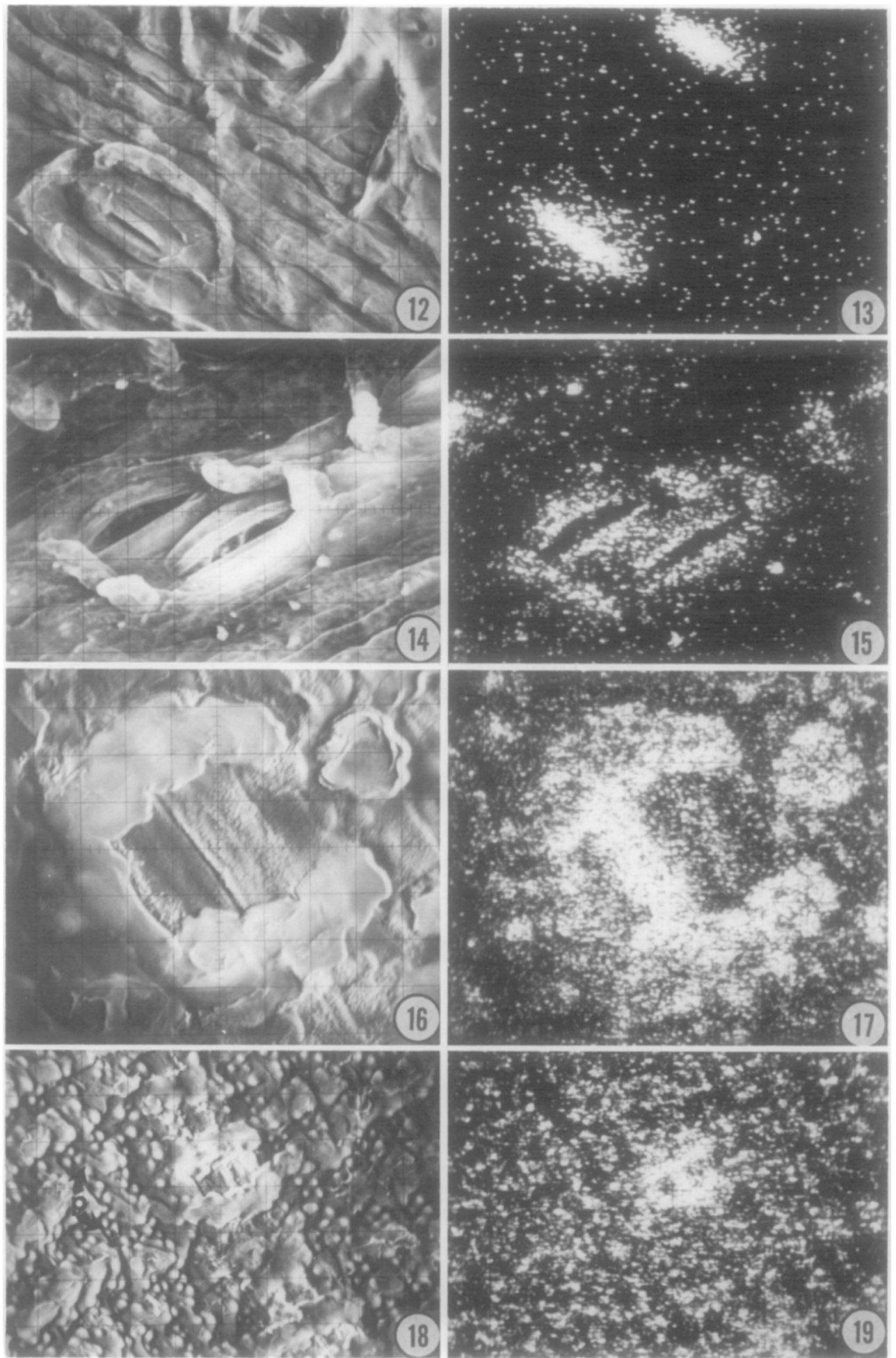
isolated cuticle from $E$. hyemale var. affine is less than in the intact cell walls. Our observations are consistent with the idea of a $\mathrm{SiO}_{2}$ gradient from the cell wall to the cuticle as proposed by Laroche (1969) and Pant and Kidwai (1968).

From our previous studies on mature oat, $E$. arvense, $E$. hyemale shoots, rice (Kaufman et al., 1969, 1971; Soni et al., 1972) and the developmental data on $E$. hyemale presented here, we have now established that $\mathrm{SiO}_{2}$ becomes deposited in the long epidermal cell walls late in internodal extension. The adaptive significance is that this provides an alternative mechanism for strengthening the developing shoot other than that provided by lignin deposition in the cellulose framework of the cell wall (Siegel, 1968; Timell, 1964). In contrast, the deposition of $\mathrm{SiO}_{2}$ in the stomata and in epidermal papillae probably has little to do with this mechanism, and these may be deposition sites for excess silicic acid, $\mathrm{Si}(\mathrm{OH})_{4}$, conducted upward in the xylem of developing shoot systems (Frey-Wyssling, 1930; Jones and Handreck, 1965). When these sites become saturated, the cell walls could then become the primary deposition sites late in development of the internodal system. The observation here of $\mathrm{SiO}_{2}$ first appearing in the stomatal apparatuses can be explained by the stomata being open early in development, when stomatal transpiration is active, compared with later (when internodes are over half their final length), when the stomata become permanently shut by an interlocking of cell walls at the aperture (Dayanandan, manuscript in preparation).
A comparison of the silica deposition patterns in internodes of two species of Equisetum that we have studied (Kaufman et al., 1971; the present work) indicates remarkable differences in the $\mathrm{X}$-ray scans for $\mathrm{SiO}_{2}$ in the stomatal apparatuses and adjacent epidermal cells (Figs. 20-23). In the annual scouring rush, $E$. arvense, (Figs. 20 and 21), the $\mathrm{SiO}_{2}$ occurs almost exclusively in papillae on the surfaces of stomata and surrounding epidermal cells. In contrast, in the perennial scouring rush, E. hyemale var affine (Figs. 22 and 23), it has been shown here that $\mathrm{SiO}_{2}$ occurs in the walls of the stomata subsidiary cells, in epidermal papillae, and in both radial and tangential walls of long epidermal cells. It is obvious from this comparison that the $\mathrm{SiO}_{2}$ deposition sites are markedly different for the two species of Equisetum and may explain why shoots of $E$. arvense are ephemeral, whereas those of E. hyemale var. affine persist for several years. The fact that $\mathrm{SiO}_{2}$ occurs in walls of the long epidermal cells, which provide the primary skeletal matrix in the epidermal system in the last-named species, but not in the first, gives strong evidence in support of this observation. The support provided by silicification late in development of elongating internodes of the perennial scouring rush is most closely analagous to the pattern we have described for elongating internodes of grasses (Kaufman et al., 1969, 1972). The adaptive significance is that silicification of both radial and tangential walls of long epidermal cells, as scen in the perennial scouring rush and in rice internodes, provides a complete jacket of silica-impreg-

FIGS. 12-19. Secondary electron (left series) and X-ray images (right series) for $\mathrm{SiO}_{2}$ in epidermal system of the developing internode. Figs. 12 and 13. Stomatal apparatus from internode 3 . Greater amounts of $\mathrm{SiO}_{2}$ are seen in these two stomata. $\times 375$. Figs. 14 and 15 . Stomata occurring as doublet in internode 5 . Greater amounts of $\mathrm{SiO}_{2}$ along ridges and aperture of these structures. $\times 375$. Figs. 16 and 17. Stomatal apparatus and epidermis of a mature internode. $\mathrm{SiO}_{2}$ deposited in epidermal knobs as well as apparatus. $\times 750$. Figs. 18 and 19. Stomatal apparatus and epidermis of a mature internode. $\mathrm{SiO}_{2}$ deposited in apparatus and the papillae (arrow) along the radial walls (top left to lower right) of the long epidermal cells. $\times 300$. 

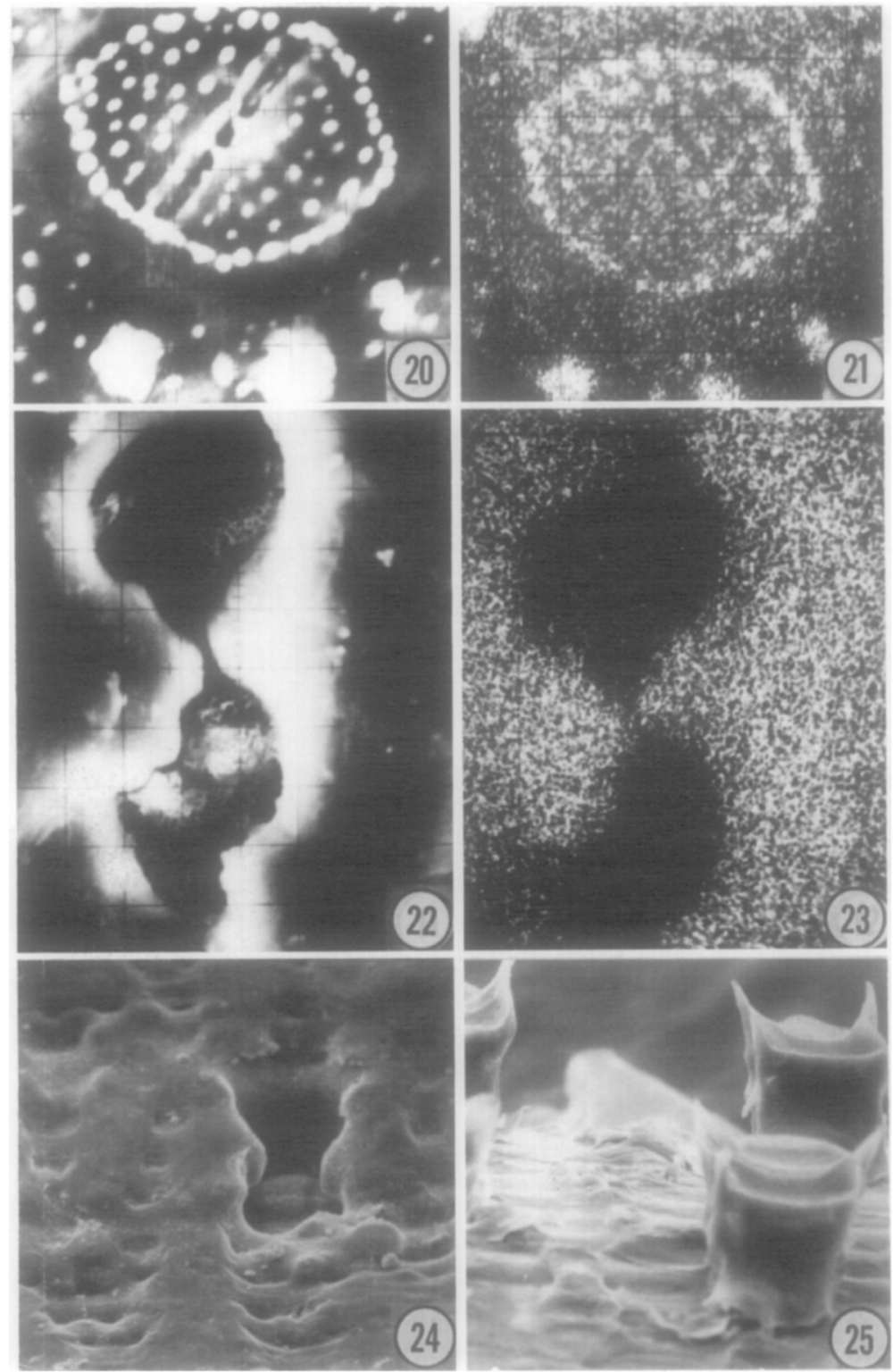

Figs. 20-23. Secondary electron (left series) and X-ray images (right series) comparing $\mathrm{SiO}_{2}$ deposition patterns in internodes of two species of Equisetum. Figs. 20 and 21. Pattern of deposition in two knobs (bottom) and in stomatal papillae (upper middle) of Equisetum arvense. $\times 675$. Figs. 22 and $23 . \mathrm{SiO}_{2}$ in the outer epidermal walls but lacking (see text for details as to why) in the very deep hourglass-shaped crypt of 2-yr-old shoots of E. hyemale. $\times 675$.

FIGs. 24 and 25. SEM view of stomatal crypt of 2-yr-old shoot of Equisetum hyemale (Fig. 24) and cellulose acetate SEM replica of two stomatal crypts (Fig. 25) showing actual depth of the stomatal crypt (ca. $65 \mu \mathrm{m}) . \times 450$.

nated cellulose to support the shoot. This is essential for older internodes and/ or sheaths so as to provide support for the younger developing parts of the aerial shoot system and for the emergence of reproductive structures.

We gratefully acknowledge the technical work of Mrs. Peggie Hollingsworth and Mr. Terry Taylor on 
the SEM. We thank Dr. Richard L. Hauke for the identification of Equisetum hyemale var. affine and Mr. Louis Martonyi for his help with the photographic work.

\section{REFERENCES}

Beaman, D. R., and Isasi, J. A. (1971). Electron beam microanalysis. Mater. Res. Standards 11, $12-56$.

CarLisLe, E. M. (1970). Silicon: a possible factor in bone calcification. Science 167, 279-280.

Chen, C., and Lewin, J. (1969). Silicon as a nutrient element for Equisetum arvense. Can. J. Bot. 47, 125-131.

Frey-Wrssling, A. (1930). Ober die Ausscheidung der Kieselsäure in der Pflanze. Ber. Deut. Bot. Ges. 48, 179-183.

Jones, L. H. P., and HandReck, K. A. (1965). Studies of silica in the oat plant. III. Uptake of silica from soils by the plant. Plant Soil 23, 79-96.

Kaufman, P. B., Bigelow, W. C., Petering, L. B., and Drogosz, F. B. (1969). Silica in developing epidermal cells of Avena internodes: electron microprobe analysis. Science 166, 1015-1017.

Kaufman, P. B., Bigelow, W. C., Schmid, R., and GHOSHEң, N. S. (1971). Electron microprobe analysis of silica in epidermal cells of Equisetum. Amer. J. Bot. 58, 309-316.

Kaufman, P. B., Soni, S. L., LaCroix, J. D., Rosen, J. J., and Bigelow, W. C. (1972). Electron-probe microanalysis of silicon in the epidermis of rice (Oryza sativa L.) internodes. Planta 104, 10-17.

Kứster, E. (1951). "Die Pflanzenzelle," 2nd ed. Fischer, Jena.

LAROCHE, J. (1967). Localisation de la silice par le microanalyseur à sonde électronique. C. R. Acad. Sci. Ser. D 265, 1695-1697.

Laroche, J. (1968). Contribution à l'étude de
l'Equisetum arvense L. III. Recherches sur la nature et la localisation de la silice chez le sporophyte. Rev. Gén. Bot. 75, 65-116.

LAROCHE, J. (1969). État de la silice sur et dans la membrane épidermique des organes aériens stériles d'Equisetum arvense L. Rev. Gén. Bot. 76, 483-489.

Laroche, J. Guervin, C., Lecoq, C., and Dao, Vo THI. (1970). Intérêt taxonomique de l'excrétion siliceuse chez les Equisétacées. C. R. Acad. Sci. Ser. D. 270, 2958-2960.

LewIN, J. C. (1962). Silicification. In "Physiology and Biochemistry of Algae" (R. A. Lewin, ed.), pp. 445455. Academic Press, New York.

Lewin, J. D., and ReimanN, B. E. F. (1969). Silicon and plant growth. Annu. Rev. Plant Physiol. 20, 289-304.

Lovering, T. S., and ENGei, C. (1967). Translocation of silica and other elements from rock into Equisetum and three grasses. U.S. Geol. Survey Prof. Pap. 594-B, pp. 1-16.

Pant, D. D., and KidwaI, P. F. (1968). Development of stomata in Equisetum. Ann. Bot. 32, 601-608.

RieknER, F. (1925). Uber Bau und Funktion der Spaltöffnungsapparate bei den Equisetinae und Lycopodiinae. Planta 1, 260-300.

Schafer, P. W., and Chandler, J. A. (1970). Electron probe X-ray microanalysis of a normal centriole. Science 170, 1204-1205.

SIEGEL, S. M. (1968). Biochemistry of the plant cell wall. In "Comprehensive Biochemistry" (M. Florkin and E. H. Stotz, eds.), Vol. 26, pp. 1-51. Elsevier, Amsterdam.

Soni, S. L., Kaufman, P. B., and Bigelow, W. C. (1972). Electron probe analysis of silicon and other elements in leaf epidermal cells of the rice plant (Oryza sativa L.). Amer. J. Bot. 59, 38-42.

Timell, T. E. (1964). Studies on some ancient plants. Sv. Papperstidn. 67, 356-363. 